\title{
ETHICAL LEADERSHIP ENHANCE POSITIVE WORK OUTCOME: A MEDIATION MODEL
}

\author{
Amna Ali ${ }^{1 *}$, Rao Aamir Khan ${ }^{2}$, Waqar Alam ${ }^{3}$, Adil Adnan ${ }^{4}$, Zaigham Aabbas ${ }^{5}$ \\ ${ }^{1 *}$ Assistant Professor, Iqra National University, Pakistan; ${ }^{2}$ Assistant Professor, Department of Management Sciences, \\ Comsats University, Islamabad, Pakistan; ${ }^{3}$ Abasyn University, Pakistan; ${ }^{4,5}$ Iqra National University, Pakistan. \\ Email: 1*am_pk97@yahoo.com, ${ }^{2}$ rao_aamir@comsats.edu.pk, ${ }^{3}$ waqar.alam@abasyn.edu.pk, ${ }^{4}$ adil_adnan99@yahoo.com, \\ ${ }^{5}$ zaigham@inu.edu.pk
}

\section{Article History: Received on $21^{\text {st }}$ April 2021, Revised on $30^{\text {th }}$ April 2021, Published on $1^{\text {st }}$ May 2021}

\begin{abstract}
Purpose of the study: The current study was conducted to find out the relationship amongst the Ethical leadership and job outcome's (job satisfaction and job performance), and to have in-depth into how the relationship between ethical leadership and the job outcomes is mediated by the psychological empowerment.

Methodology: The study has been conducted in the public sector hospitals of district Peshawar. Data was collected from 267 nurses working in public sector hospitals. Data was collected through a structured questionnaire, and convenience sampling was used as a sampling technique. In order to test the hypothesis, the regression-mediation analyses were considered.

Main Findings: The result revealed that ethical leadership has a positive impact on job satisfaction and the job performance. Similarly, the psychological empowerment also had a positive relationship with job satisfaction and job performance. Findings of the study also show partial mediation of Psychological empowerment in the relationship of ethical leadership and job satisfaction. Moreover, psychological empowerment fully mediates the relationship between ethical leadership and job performance.
\end{abstract}

Applications of this study: On practical grounds, our study provides guidelines for managing human resources in organizations. Employees need a good platform where they are provided with opportunities to build an interactive relationship with the supervisors which results in the progressive output for both individuals, and the performance of organizations.

Novelty/Originality of this study: Unfortunately, less importance has been given to the relationship of ethical leadership with job outcomes like performance. Few studies have explained that how and why ethical leadership is related to employee job performance. This study presents that ethical leadership affects employees by modelling and motivating them to avoid those unethical and harmful behaviours for their performance.

Keywords: Ethical Leadership, Job Satisfaction, Job Performance, Psychological Empowerment.

\section{INTRODUCTION}

\section{Background of the Study}

Change that an organization faces nowadays can be effectively and efficiently managed if the organization's leaders show flexibility and have the capabilities to adopt change according to the new situations. One of the positive influences of leadership over employees is to motivate them to show maximum efforts that are meaningful for the employee and organization. Recently Mayer, Acquino, Green Baum, and Kuenzi (2012) put an important question: What effect does leadership have on employee behaviour? They put this question according to the antecedent and consequences of ethical leadership. Unethical leaders cost the organization with billions of dollars every year (Detert et al., 2007). Unethical leaders cost the organization for their interest (Schaubroeck et al., 2007; Naeem et al., 2020). Trevino and Brown (2004) argued that unethical behaviour exists from the start of human civilization. Leadership must be ethical to achieve an effective and meaningful working environment for a longer time, and leaders must act as a role model (Grojean et al., 2004).

Unfortunately, less importance has been given to the relationship of ethical leadership with job outcomes like performance (Walumbwa et al., 2011, Piccolo et al., 2010). Few studies have explained that how and why ethical leadership is related to employee job performance. The social learning perspective best explains the relationship between ethical leadership and job performance.

Based on this framework, ethical leadership affects employees by modelling and motivating them to avoid those behaviours that are unethical and harmful to their performance (Kim, \& Vandenberghe, 2020; Piccolo et al., 2010). Few researchers have explained how ethical leadership affects employee performance (Piccolo et al., 2010; $\underline{\text { Walumbwa et al., }}$ 2010, 2012). Previous researchers used trust as a mediator (Pillai et al., 1999; Schauibroeck et al., 2001).

To find out how ethical leadership influences nurses' job satisfaction and job performance is the main purpose of this study. One of the basic purposes of the study is to find out the effect of ethical leadership on job satisfaction and job performance with the inclusion of psychological empowerment as a mediator. 


\section{Rationale/need of the study}

In the effective and efficient management of the organization, leadership plays a key and vital role. One of the key roles of the leader is to make the employees ethically sound and motivate them to behave in ethical manners and avoid destructive and unethical behaviours. Specifically, ethical leaders are perceived by the followers as role models. There is a positive relationship between ethical leadership and follower job performance and job satisfaction. Unfortunately, less attention has been given to the relationship of ethical leadership with job outcomes (Piccolo et al., 2010; Walumbwa et al., 2011). Now the question arises that how ethical leadership affects job outcomes and why psychological empowerment acts as a mediator in the relationship of ethical leadership and job outcomes? A basic framework that explains how ethical leadership influences job outcomes is the social learning perspective. Only a few studies explain a process through which ethical leadership influences employee job outcomes (McKenna, \& Jeske, 2021; Piccolo et al., 2010; Walumbwa et al., 2011). Previous researchers used to trust and many other variables like psychological capital, affective commitment, LMX, psychological ownership, self-efficacy as a mediator with different outcomes. Most of the studies in this regard has been conducted in non-Asian countries. This study aims to focus on Pakistani culture and find out the influence of ethical leadership on job outcomes with the inclusion of psychological empowerment as a mediator.

\section{Objectives of the Study}

1. To investigate the effect of ethical leadership on job outcomes, i.e., job satisfaction and job performance

2. To examine the mediating effect of psychological empowerment in the relationship of ethical leadership, job satisfaction, and job performance

\section{LITERATURE REVIEW}

\section{Hypotheses and Theory Development \\ Ethical Leadership and Job Performance}

Now a day's increased attention has been given to morally acceptable practices, and managers give importance to ethical leadership (Trevino et al. 2006). Bandura's (1997) Social Learning Theory explains the process that how leaders influence employee performance. According to this theory, leaders influence their followers by modelling (Walumbwa \& Schaubroock, 20009). Through role modelling, an individual can learn what the right and appropriate behaviour at the job is. Ethical leaders attract their followers, motivate them and help them perform their work (Bandura, 1986).

There is a positive relationship between Ethical leadership and job performance because these leaders punish and reward the employees for adopting appropriate behaviour and telling the employees what is right behaviour. Ethical leadership is positively related to job performance and citizenship behaviour (Piccolo et al., 2010).

H1: Ethical leadership significantly affects the job satisfaction.

\section{Ethical Leadership and Job Satisfaction}

A strong association exists between Ethical leadership and job satisfaction. "They state that subordinates show a high level of job satisfaction in the presence of ethical leaders because these leaders treat their followers fairly and exhibit a transformational style of leadership" (Brown \& Trevino, 2006). According to Brown and Trevino (2006), ethical leadership holds a positive relationship with job satisfaction. Neubert et al. (2009), ethical leadership has both direct and indirect effects on job satisfaction. Ethical leaders influence job satisfaction because they encourage an ethical climate. Many researchers found a positive relationship between ethical leadership and outcomes like job satisfaction, organizational commitment, and organization citizenship behaviour (Brown \& Trevino, 2006).

H2: Ethical leadership significantly affects job performance.

\section{Ethical Leadership and Psychological Empowerment}

Ethical leaders focus on the employee's developmental needs and ensure the employees that there is a fit and their job are important (May et al., 2004). Instead of a means to an end, these leaders respect their followers and involve them in decision-making. Such respect makes the employee feel meaning at their job; because the employees' goals are consistent with the organization's goals (May et al., 2004). Ethical leaders enhance individual self-efficacy and will have a high level of competence in their positions (Bandura, 1986). Ethical leaders motivate the employees to be engaged at work (May et al., 2004). Ethical leaders take care of human rights, which help the employee develop greater empowerment feelings (May et al., 2004).

H3: Ethical leadership significantly affects psychological empowerment.

\section{Psychological Empowerment and Job Performance}

Psychological empowerment has a positive relationship with several outcomes like employee job satisfaction, commitment, and performance (Koberg et al., 1999; Liden et al., 2000). A positive relationship exists between psychological empowerment and job performance because highly empowered employees feel affections about their job or task activities (Speritzer, 1995). According to Spector (1986), participation and autonomy are positively associated 
with job performance. According to several theories (Hackman \& Oldham, 1976), highly motivated employees will show greater satisfaction and put extra effort to perform their tasks. Seibert et al. (2011) found that commitment, satisfaction, and job performance are positively related.

H4: Psychological empowerment significantly affects the job satisfaction.

\section{Psychological Empowerment and Job Satisfaction}

According to Speritzer et al. (1997), employee job satisfaction is an outcome of psychological empowerment and found that Psychological empowerment positively influences job satisfaction. Psychological empowerment affects job satisfaction, commitment, and job performance positively (Speritzer et al., 1997). Spritzer et al. (1997) found a strong relationship between meaning and job satisfaction. Meaning and competence are also positively related to job satisfaction (Carless, 2004).

H5: Psychological empowerment significantly affects job performance.

\section{Mediating Role of Psychological Empowerment}

Empowerment has several relational, social, structural, and psychological (Liden et al., 2000). Thomas and Venthouse (1990) and Speritzer (1995) mentioned four dimensions of empowerment that reflect an individual orientation to the specific task. The dimensions includes the role meaning, the competence, the self-determination, and the impact. The role meaning is related to when employees consider that their jobs are important and valuable (May et al., 2004; Fulford \& Enz, 1995). When the values of individual are congruent with the mission or goal of the organization, individuals consider their job is an important one which makes them satisfied (May et al., 2004; Quinn \& Spretizer 1997; Spretizer 1995; Thomas \& Tymon, 1994; Thomas \& Venthouse, 1990).

Ethical leaders facilitate employees task-related skills and provide opportunities that help them make tough ethical decisions; such leaders enhance individuals' self-efficacy and have a high level of competence in their position, which is an important dimension of psychological empowerment (Bandura, 1986). Hence these employees will show high performance and job satisfaction because employees with a high level of psychological empowerment show high job performance (Deci et al., 1989). Psychological empowerment enhances employee job satisfaction because psychological empowerment is a strong predictor of job satisfaction (Carless, 2004).

H6(a): Psychological empowerment significantly mediates the relationship between ethical leadership and job outcomes, i.e., job satisfaction.

H6(b): Psychological empowerment significantly mediates the relationship between ethical leadership and job outcomes, i.e., job performance.

\section{RESEARCH METHODOLOGY}

\section{Population and Sample size}

The population for the current study comprised of the female nurses serving in hospitals of district Peshawar. Nevertheless, the constraints such as the time, non-accessibility of some data, and also the finance were some of the concerns to due to which the study focused on the targeted population. The population selected for this study were the nurses (female) from Khyber Teaching Hospital and Lady Reading Hospital Peshawar. According to the data provided by the registrars of these hospitals, 800 was the approximate figure of the nurses serving in the aforementioned hospitals.

\section{Data Collection}

This study was based on primary data collected from female nurses of Khyber Teaching Hospital and Lady Reading Hospital through a structured questionnaire. Responses for all the variables were measured based on a five-point Likert scale ranging from 1 " strongly disagree" to 5 "strongly agree". A questionnaire was distributed personally by hand.

\section{Variables and their Measurement}

Ethical leadership:

Ethical leadership can be defined as leadership that affects belief, behavior and makes the followers motivated to engage in ethical behavior (Shamer et al. 1993). EL behavior was measured with 10- item ELS provided by Brown et al., (2005).

\section{Job Performance}

Job performance can be defined as the goods or services delivered by an employee due to tasks assigned to employees with some limits. Job performance was measured with a 7-items scale by William and Anderson (1991).

\section{Job Satisfaction}

Job satisfaction can be defined as a general affective evaluation of an individual about a job is called job satisfaction. Job 
satisfaction will ensure that the employee shows a positive response. Job satisfaction was measured by using a 6-items scale developed by Vogoda (2004).

\section{Psychological Empowerment}

Psychological empowerment can be defined as a comprehensive process composed of intrinsically motivated orientation toward work. (Conger \& Kunango, 1988; Spertizer, 1995; Thomas \& Venthouse, 1990). Spreitzer's (1995) 12-item scale was used to measure psychological empowerment.

\section{Theoretical Frame Work}

The theoretical framework for the current study is presented in figure 1.0. The theoretical framework for this study incorporates an independent variable ie. EL. This framework was labelled by two dependent variables job performance and job satisfaction. This framework also contained one mediating variable psychological empowerment. The following figure shows the theoretical framework for this study.

\section{Dependent Variables}

\section{Independent Variable}

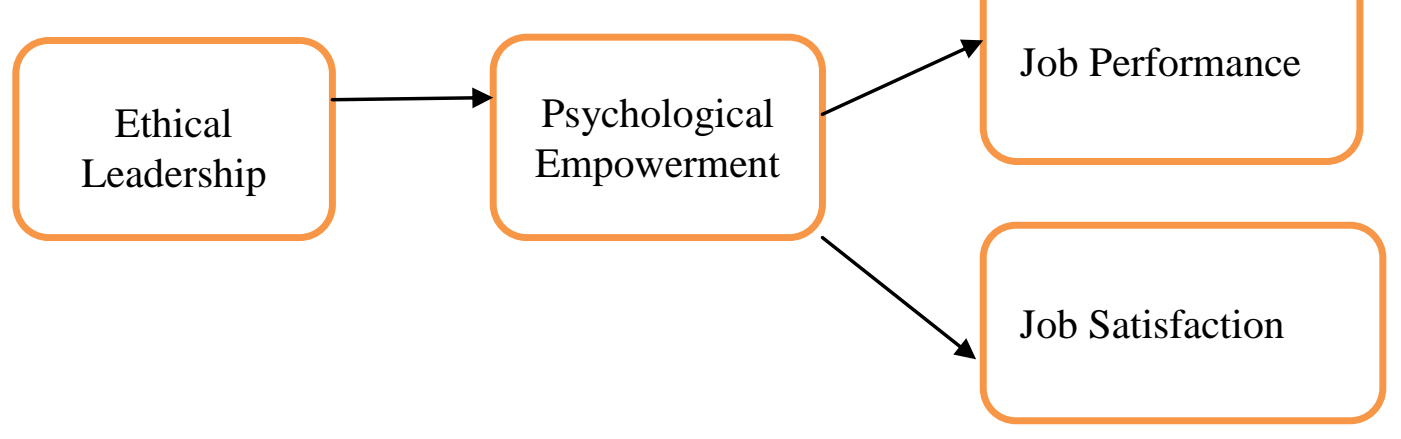

Figure 1: Theoretical Model

Source: Author conceptualization

\section{RESULTS AND DISCUSSION}

\section{Reliability Analysis}

Cronbach's alpha $(\alpha)$ represents the coefficient of reliability. The value of $(\alpha)$ lies between 0 and 1.Higher the value of alpha, the higher will be the internal consistency of items. According to the standard provided by Cronbach (1951), an alpha score of 0.70 or greater will be considered good reliability.

Table 1: Variables Reliability Measurement

\begin{tabular}{llll}
\hline Variable & No. of Items & Alpha Score & Reliability \\
\hline Ethical leadership & 10 & 0.89 & Reliable \\
\hline Psychological empowerment & 12 & 0.87 & Reliable \\
\hline Job satisfaction & 6 & 0.81 & Reliable \\
\hline Job performance & 7 & 0.722 & Reliable \\
\hline
\end{tabular}

The above shows the measurement of reliability of variables to know that whether variables were reliable or not. The value of Cronbach's alpha shows that the data collected for each variable was reliable. According to Cronbach (1951), if the value of alpha for each variable is greater than $70 \%$, it means the data collected is reliable.

\section{Mediation Analysis: step-1}

The below table explains regression analysis between the independent variable Ethical leadership, and the dependent variable, job satisfaction. This table is interpreted as follow:

Table 2: Direct Relationship between Independent and Dependent Variable

\begin{tabular}{cccccc}
\hline \multirow{2}{*}{ Model } & \multicolumn{2}{c}{$\begin{array}{c}\text { Un-standardized } \\
\text { Coefficients }\end{array}$} & \multicolumn{3}{c}{$\begin{array}{c}\text { Standardize } \\
\text { Coefficients }\end{array}$} \\
\cline { 2 - 6 } & B & $\begin{array}{c}\text { Std. } \\
\text { Error }\end{array}$ & Beta & t-ratio & Sig. \\
& & & & 8.051 & 0.000 \\
Ethical leadership & 0.617 & 0.050 & 0.656 & 12.274 & 0.000 \\
\hline
\end{tabular}


Dependent variable: job satisfaction: $F=150.651, P=0.000, \mathrm{R}^{2}=0.331$

In this model, the value of $\mathrm{F}$ was 149.82 with p-value equals to 0.000 , which is however less than 0.05 and shows a significant relationship, and data was fitting an overall model. The value of $\mathrm{R}^{2}$ was 0.331 , which shows that the independent variable Ethical leadership explained 33\% variation in the dependent variable job satisfaction, and the rest of the variation in job satisfaction was due to some factors of the job satisfaction that are not included in the study. The regression coefficient value was 0.617 , which means that per unit change in Ethical leadership will bring $61 \%$ change in the dependent variable job satisfaction. The significance level in this relationship was 0.000 , which was less than 0.05 and significant. Therefore we rejected $\mathrm{H} 0$ and accept $\mathrm{H} 1$ (ethical leadership significantly affects job satisfaction) that a significant relationship exists between ethical leadership and job satisfaction. These findings of the study were in resonance with the finding of Brown and Trevino (2006), who noticed ethical leadership was positively related to job satisfaction.

Table 3: Direct Relationship between Independent and Dependent Variable

\begin{tabular}{cccccc}
\hline \multirow{2}{*}{ Model } & \multicolumn{2}{c}{$\begin{array}{c}\text { Un-standardized } \\
\text { Coefficients }\end{array}$} & \multicolumn{3}{c}{$\begin{array}{c}\text { Standardize } \\
\text { Coefficients }\end{array}$} \\
\cline { 2 - 6 } & B & $\begin{array}{c}\text { Std. } \\
\text { Error }\end{array}$ & Beta & t-ratio & Sig. \\
\hline (Constant) & 2.126 & .373 & & 5.702 & 0.000 \\
Ethical leadership & 0.450 & .088 & 0.339 & 5.089 & 0.000 \\
\hline
\end{tabular}

Dependent variable: job performance: $\mathrm{F}=25.897, \mathrm{P}=0.000, \mathrm{R}^{2}=0.11$

The above explains regression analysis between the independent variable Ethical leadership and dependent variable Job performance. In table 4.9 , the value of $\mathrm{F}$ mentioned is 25.77 , p value is 0.000 , which is lesser than 0.05 , and showed overall model fitness. $\mathrm{R}^{2}$ was 0.11 , which explains that the independent variable ethical leadership explained $11 \%$ variation in the dependent variable job performance. Since the value of $\mathrm{R}^{2}$ was positive but very low, which indicates that the rest of the variation in the dependent variable was due to other factor. The regression coefficient value was 0.450. The value specifies that bringing one unit increase in EL will lead towards $45 \%$ increase in JP. we bring a per unit increase in Ethical leadership, it will bring a $45 \%$ increase in job performance. The value of significance level between Ethical leadership and job performance was 0.000 , which was less than 0.05 , which shows that this relationship was significant. Therefore we accepted hypothesis No2 (ethical leadership significantly affects job performance) and concluded that the relationship between Ethical leadership and job performance was significant. These findings of the study were in resonance with the findings of Piccolo et al. (2010), who examined the positive association between ethical leadership and the job performance.

\section{Mediation Analysis step-2}

Table 4: Relationship between Independent and Mediator Variable

\begin{tabular}{cccccc}
\hline \multirow{2}{*}{ Model } & \multicolumn{2}{c}{$\begin{array}{c}\text { Un-standardized } \\
\text { Coefficients }\end{array}$} & \multicolumn{3}{c}{$\begin{array}{c}\text { Standardize } \\
\text { Coefficients }\end{array}$} \\
\cline { 2 - 6 } & B & $\begin{array}{c}\text { Std. } \\
\text { Error }\end{array}$ & Beta & t-ratio & Sig. \\
\hline (Constant) & 0.869 & 0.122 & & 7.125 & 0.000 \\
Ethical leadership & 0.795 & 0.029 & 0.890 & 27.506 & 0.000 \\
\hline
\end{tabular}

Dependent variable: psychological empowerment: $\mathrm{F}=756.591, \mathrm{P}=0.000, \mathrm{R}^{2}=0.352$

The table explains the relationship between the independent variable and the intervening variable. This table shows the effect of Ethical leadership on mediating variable psychological empowerment. Table 4.8 .3 the value of $F=752.476$ with $\mathrm{p}<0.05$, which indicates that the data was fitting the overall model. The value of $\mathrm{R}^{2}$ was 0.352 , which shows that the independent variable Ethical leadership explained 35\% variation in the mediating variable Psychological empowerment. The regression coefficient value was 0.795 , which shows that per unit increase in Ethical leadership will bring $79 \%$ change in the mediating variable psychological empowerment. P-value was less than 0.05 , which shows that relation is significant at alpha $=0.05$. Thus we accepted Hypothesis No.3 (ethical leadership significantly affects psychological empowerment) that the relationship between Ethical leadership and Psychological empowerment was significant. The study's findings were in resonance with the findings of May et al. (2004), who found that ethical leaders protect basic human rights which help the employees develop greater feelings of Psychological empowerment and show high performance and job satisfaction.

Mediation analysis: step-3

Table 5: Relationship between Mediator and Dependent Variables

\begin{tabular}{ccc}
\hline Model & $\begin{array}{c}\text { Un-standardized } \\
\text { Coefficients }\end{array}$ & $\begin{array}{c}\text { Standardize } \\
\text { Coefficients }\end{array}$ \\
\hline
\end{tabular}




\begin{tabular}{cccccc}
\hline & B & $\begin{array}{c}\text { Std. } \\
\text { Error }\end{array}$ & Beta & t-ratio & Sig. \\
\hline (Constant) & 1.338 & 0.234 & & 5.710 & 0.000 \\
Psychological empowerment & 0.704 & 0.055 & 0.669 & 12.682 & 0.000 \\
\hline
\end{tabular}

Dependent variable: job satisfaction: $\mathrm{F}=160.822, \mathrm{P}=0.000, \mathrm{R}^{2}=0.347$

The relationship between mediator (Psychological empowerment) and job satisfaction was explained in table 4.12. Pvalue for $\mathrm{F}$ was $.000 \leq 0.05$, which indicates that data was fitting the overall model. $\mathrm{R}$ square was 0.347 , which explains that $34 \%$ variation was explained by psychological empowerment in the job satisfaction which is the independent variable. Other variation mentioned was because of the other factors of Job satisfaction which are not considered for the study. The regression coefficient value or B was .704which indicates that per unit change in psychological empowerment will bring a $70 \%$ change in job satisfaction. P-value $=.000$, which was less than 0.05 , and the relationship was significant. Based on the significance level, we reject $\mathrm{H} 0$ and accepted Hypothesis No.4 (psychological empowerment significantly affects job satisfaction) that the relationship between psychological empowerment and job satisfaction was significant. These findings of the study were in alliance with Liden et al. (2000), who stated that Psychological empowerment was positively related to job satisfaction and job performance.

Table 6: Relationship between Mediator and Dependent Variable

\begin{tabular}{cccccc}
\hline \multirow{2}{*}{ Model } & \multicolumn{2}{c}{$\begin{array}{c}\text { Un-standardized } \\
\text { Coefficients }\end{array}$} & \multicolumn{3}{c}{$\begin{array}{c}\text { Standardize } \\
\text { Coefficients }\end{array}$} \\
\cline { 2 - 6 } & B & $\begin{array}{c}\text { Std. } \\
\text { Error }\end{array}$ & Beta & t-ratio & Sig. \\
& & 0.413 & & 4.1959 & 0.000 \\
(Constant) & 1.734 & 0.098 & 0.365 & 5.536 & 0.000 \\
psychological & 0.542 & 0 & & & \\
Empowerment & & & &
\end{tabular}

Dependent variable: job performance: $\mathrm{F}=30.650, \mathrm{P}=0.000, \mathrm{R}^{2}=0.13$

The relationship between psychological empowerment and job performance was explained in table 4.13. F carries its value as 30.514 with $\mathrm{p}=.000 \leq 0.05$, indicating that data fits the model. The $\mathrm{R}^{2}$ value was 0.13 , which showing that $13 \%$ of the variation was described by psychological empowerment in the job performance(dependent variable). Since the value of $\mathrm{R}^{2}$ was positive and very low, this indicates that the rest of the variation in job performance was due to some factors of job performance that are not specified in the study. The value of $\mathrm{B}$ was 0.542 , which indicates that per unit change in psychological empowerment will bring a 54\% change in job performance. P-value was significant at $\alpha=0.05$, which means that the relationship between psychological empowerment and job performance was significant. Therefore, we accepted hypothesis No.5 (psychological empowerment significantly affects job performance) and concluded that job performance was positively influenced by psychological empowerment. These findings were in resonance with Liden et al. (2000), who founded that Psychological empowerment and job performance are positively related.

\section{Mediation Analysis: step- 4}

Table 7: Independent- Dependent Relationship with Inclusion of Mediating Variable

\begin{tabular}{cccccc}
\hline \multirow{2}{*}{ Model } & \multicolumn{3}{c}{$\begin{array}{c}\text { Un-standardized } \\
\text { Coefficients }\end{array}$} & \multicolumn{3}{c}{$\begin{array}{c}\text { Standardize } \\
\text { Coefficients }\end{array}$} \\
\cline { 2 - 6 } & $\mathbf{B}$ & $\begin{array}{c}\text { Std. } \\
\text { Error }\end{array}$ & Beta & t-ratio & Sig. \\
& & & & & \\
\hline (Constant) & 1.338 & 0.234 & & 5.710 & 0.000 \\
Psychological Empowerment & $\mathbf{0 . 7 0 4}$ & 0.055 & 0.669 & 12.6832 & 0.000 \\
\hline (Constant) & 1.337 & 0.2321 & & 5.788 & 0.000 \\
Psychological & $\mathbf{0 . 4 2 7}$ & 0.120 & 0.406 & & \\
Empowerment & & & & 3.562 & 0.000 \\
Ethical leadership & 0.278 & 0.107 & .2965 & 2.594 & 0.010 \\
\hline
\end{tabular}

Dependent variable: job satisfaction: $F=160.822, p=0.000, R^{2}=0.31$

The table explains the regression analysis between the independent variable Ethical leadership and the dependent variable job satisfaction with mediating variable psychological empowerment. The regression coefficient for ethical leadership in the mediation analysis has reduced from 0.617 to 0.278 , which shows that Psychological empowerment partially mediated the relationship between Ethical leadership and job satisfaction, which was significant at each step. Similarly, both $\mathrm{X}$ and $\mathrm{M}$ were still significant after controlling $\mathrm{M}$, which shows partial mediation. Hence these findings supported hypothesis no 6(a) (psychological empowerment is significantly mediating the association between ethical leadership and job outcome, i.e., job satisfaction and also a connection between Ethical leadership and job satisfaction 
was significantly mediated by Psychological empowerment. These findings were in resonance with the finding of Bandura (1986) that Ethical leaders develop task-related skills, self-efficacy and have high competence in his /her position, which is an important dimension of psychological and also according to Speritzer et al. (1997), job satisfaction is an outcome of psychological empowerment. A positive relationship exists between psychological empowerment and job satisfaction.

Table 8: Independent- Dependent Relationship with the Inclusion of Mediator

\begin{tabular}{cccccc}
\hline \multirow{2}{*}{ Model } & \multicolumn{3}{c}{$\begin{array}{c}\text { Un-standardized } \\
\text { Coefficients }\end{array}$} & \multicolumn{3}{c}{$\begin{array}{c}\text { Standardize } \\
\text { Coefficients }\end{array}$} \\
\cline { 2 - 7 } & $\mathbf{B}$ & $\begin{array}{c}\text { Std. } \\
\text { Error }\end{array}$ & Beta & t-ratio & Sig. \\
\hline (Constant) & 1.734 & 0.413 & & 4.1955 .536 & 0.000 \\
Psychological Empowerment & 0.542 & 0.098 & 0.365 & & 0.000 \\
\hline (Constant) & 1.734 & 0.414 & & 4.186 & 0.000 \\
Psychological & $\mathbf{0 . 4 5 2}$ & 0.215 & 0.304 & 2.101 & 0.037 \\
Empowerment & & & & & \\
Ethical leadership & .091 & 0.192 & 0.69 & .0473 & 0.637 \\
\hline
\end{tabular}

Dependent variable: job performance: $R^{2}=0.13, p=0.000$

The relationship between an independent variable and a dependent variable job performance with psychological empowerment as a mediator was explained in table 4.15. The value of B for ethical leadership dropped from 0.450 to 0.091 and was close to 0 , which suggests that Psychological empowerment fully mediated the relationship between Ethical leadership and job performance. Similarly, both X and M were no more significant after controlling M, which indicates full mediation. This relationship was tested in hypothesis No 6 (b). Psychological empowerment significantly mediates the relationship between ethical leadership and job outcomes, i.e., job performance.

\section{DISCUSSION}

The purpose of the current study was to determine how ethical leadership affects job satisfaction and job performance and how the relationship between ethical leadership, job satisfaction, and job performance was mediated by Psychological empowerment.

First of all, it was confirmed that Ethical leadership and job satisfaction were positively related. Hypothesis No.1 (ethical leadership significantly affects job satisfaction) confirmed that ethical leadership positively influences job satisfaction. The higher the value of Ethical leadership in practice, the higher the job satisfaction of employees. These findings of the study were in resonance with the finding of Brown and Trevino (2006), who noticed a positive relationship between Ethical leadership and job satisfaction. Also, these findings were in resonance with the findings of Neubert et al. (2009), who empirically found that Ethical leadership has a positive relationship with job satisfaction.

Similarly, hypothesis No.2 (ethical leadership significantly affects job performance) confirmed that Ethical leadership positively influences job performance. The findings of the study supported that ethical leadership has a positive effect on job performance. These findings of the study were in resonance with the findings of Picolo et al. (2010), who noticed that Ethical leadership has a positive relationship with job performance and citizenship behaviour, and De Hoog and Den Hartog (2008), who noticed a positive relationship between ethical leadership and job outcomes.

The study's findings also supported hypothesis No.4 (psychological empowerment significantly affects job satisfaction) and hypothesis No5 (psychological empowerment significantly affects job performance) and was concluded that psychological empowerment positively influences job outcomes, i.e. job satisfaction and job performance. Findings in this regard were in resonance with the findings of Kobert et al. (1999) and Liden et al. (2000), who examined that psychological empowerment positively affect job satisfaction and job performance. Findings were also in resonance with May et al. (2004), who found that ethical leaders protect basic human rights, which help the employees to develop greater feelings of Psychological empowerment and show high performance and job satisfaction.

The study's findings also supported the mediating effect of psychological empowerment in the relationship between Ethical leadership and job outcomes. This relationship was confirmed in hypotheses No.6 (a) and 6 (b), where we concluded that psychological empowerment partially mediated the relationship of ethical leadership with job satisfaction and fully mediated with job performance. This study supported the findings of Bandura (1986) that Ethical leaders develop task-related skills, self-efficacy and have high competence in his /her position, which is an important dimension of psychological empowerment and also with the findings of (Hackman \& Oldham, 1980), who stated that employees with a high level of psychological empowerment show high performance. Cronbach's alpha for all the variables was above $70 \%$, which shows that the data collected was reliable.

\section{CONCLUSION}

According to the study's findings, ethical leadership was positively related to job satisfaction and job performance because P-value for job satisfaction and job performance was 0.000 which was less than 0.05 , indicating that the 
relationship was significant at a significant level. The findings of the study also supported that ethical leadership and psychological empowerment are positively related. Both full and partial mediation was found in this study. The relationship between ethical leadership and job satisfaction was partially mediated by Psychological empowerment. Similarly, the relation of ethical leadership with job performance was fully mediated by psychological empowerment. All the items of the questionnaire were reliable, with Cronbach's alpha above 70\%. All the stated hypotheses of the study were tested and supported.

\section{LIMITATIONS AND FUTURE DIRECTIONS}

The study conducted not only identifies but also provides a substantial gap for future studies. The convenient sampling techniques were adapted as a sampling technique. Techniques such as simple random sampling can be used in future studies.

This study can also be explored by adding another variable like organization citizenship behaviour in the same model. Furthermore, this study was conducted in public sector hospitals to conduct future studies in other sectors like the educational sector.

\section{ACKNOWLEDGEMENT}

We would like to thank all the independent reviewers of HSSR who conducted a feasibility study of our research work.

\section{AUTHORS CONTRIBUTION}

Dr. Amna Ali, and Dr. Rao Aamir Khan wrote the research paper and design the organization of this paper; Dr. Waqar Alam, Dr. Adil Adnan, and Zaigham Abbas perform the statistical analysis, interpretations, and technical parts. Thus, all authors contributed significantly to this research.

\section{REFERENCES}

1. Anser, M. K., Ali, M., Usman, M., Rana, M. L. T., \& Yousaf, Z. (2021). Ethical leadership and knowledge hiding: an intervening and interactional analysis. The Service Industries Journal, 41(5-6), 307-329. https://doi.org/10.1080/02642069.2020.1739657

2. Bandura, A. (1986). Fearful expectations and avoidant actions as coeffects of perceived self-inefficacy. American Psychologist, 41(12), 1389-1391. https://doi.org/10.1037/0003-066X.41.12.1389

3. Brown, M. E., \& Treviño, L. K. (2006). Ethical leadership: A review and future directions. The Leadership Quarterly, 17(6), 595-616. https://doi.org/10.1016/j.leaqua.2006.10.004

4. Carless, S. A. (2004). Does psychological empowerment mediate the relationship between psychological climate and job satisfaction?. Journal of Business and Psychology, 18(4), 405-425. https://doi.org/10.1023/B:JOBU.0000028444.77080.c5

5. Conger, J. A., \& Kanungo, R. N. (1988). The empowerment process: Integrating theory and practice. Academy of management review, 13(3), 471-482. https://doi.org/10.5465/amr.1988.4306983

6. Cronbach, L. J. (1951). Coefficient alpha and the internal structure of tests. Psychometrika, 16(3), 297-334. https://doi.org/10.1007/BF02310555

7. Deci, E. L., Connell, J. P., \& Ryan, R. M. (1989). Self-determination in a work organization. Journal of Applied Psychology, 74(4), 580. https://doi.org/10.1037/0021-9010.74.4.580

8. De Hoog, A. H. B. \& Den Hartog, D. N. (2008). Ethical and despotic leadership, relationship with leader's social responsibility, top management team effectiveness and subordinates' optimism: A multi-method study. The Leadership Quarterly, 19, 297-311. https://doi.org/10.1016/j.leaqua.2008.03.002

9. Detert, J. R., Treviño, L. K., Burris, E. R., \& Andiappan, M. (2007). Managerial modes of influence and counterproductivity in organizations: A longitudinal business-unit-level investigation. Journal of Applied Psychology, 92(4), 993. https://doi.org/10.1037/0021-9010.92.4.993

10. Fulford, M. D., \& Enz, C. A. (1995). The impact of empowerment on service employees. Journal of Managerial Issues, 161-175.

11. Gecas, V. (1989). The social psychology of self-efficacy. Annual review of sociology, 15(1), 291-316. https://doi.org/10.1146/annurev.so.15.080189.001451

12. Grojean, M. W., Resick, C. J., Dickson, M. W., \& Smith, D. B. (2004). Leaders, values, and organizational climate: Examining leadership strategies for establishing an organizational climate regarding ethics. Journal of Business Ethics, 55(3), 223-241. https://doi.org/10.1007/s10551-004-1275-5

13. Hackman, J. R. (1980). Work redesign and motivation. Professional Psychology, 11(3), 445. https://doi.org/10.1037/0735-7028.11.3.445

14. Kanter, R. M. (1983). The change masters: Binnovation and entrepreneurship in the American corporation. Touchstone Book.

15. Kim, D., \& Vandenberghe, C. (2020). Ethical leadership and team ethical voice and citizenship behavior in the military: The roles of team moral efficacy and ethical climate. Group \& Organization Management, 45(4), 514555. https://doi.org/10.1177/1059601120920050 
16. Koberg, C. S., Boss, R. W., Senjem, J. C., \& Goodman, E. A. (1999). Antecedents and outcomes of empowerment: Empirical evidence from the health care industry. Group \& Organization Management, 24(1), 71-91. https://doi.org/10.1177/1059601199241005

17. Kobert, J. J. (1999). Guide to High Availability: Configuring boot/root/swap. Prentice-Hall.

18. Kristof-Brown, A. L., Zimmerman, R. D., \& Johnson, E. C. (2005). Consequences Of Individuals' fit At Work: A Meta-Analysis Of Person-Job, Person-Organization, Person-Group, And Person-Supervisor Fit. Personnel Psychology, 58(2), 281-342. https://doi.org/10.1111/j.1744-6570.2005.00672.x

19. Liden, R. C., Wayne, S. J., \& Sparrowe, R. T. (2000). An examination of the mediating role of psychological empowerment on the relations between the job, interpersonal relationships, and work outcomes. Journal of applied psychology, 85(3), 407. https://doi.org/10.1037/0021-9010.85.3.407

20. May, D. R., Gilson, R. L., \& Harter, L. M. (2004). The psychological conditions of meaningfulness, safety and availability and the engagement of the human spirit at work. Journal of Occupational and Organizational Psychology, 77(1), 11-37. https://doi.org/10.1348/096317904322915892

21. Mayer, D. M., Aquino, K., Greenbaum, R. L., \& Kuenzi, M. (2012). Who displays ethical leadership, and why does it matter? An examination of antecedents and consequences of ethical leadership. Academy of Management Journal, 55(1), 151-171. https://doi.org/10.5465/amj.2008.0276

22. Mayer, D. M., Kuenzi, M., Greenbaum, R., Bardes, M., \& Salvador, R. B. (2009). How low does ethical leadership flow? Test of a trickle-down model. Organizational Behavior and Human Decision Processes, 108(1), 1-13. https://doi.org/10.1016/j.obhdp.2008.04.002

23. McKenna, J., \& Jeske, D. (2021). Ethical leadership and decision authority effects on nurses' engagement, exhaustion, and turnover intention. Journal of Advanced Nursing, 77(1), 198-206. https://doi.org/10.1111/jan.14591

24. Naeem, R. M., Weng, Q., Hameed, Z., \& Rasheed, M. I. (2020). Ethical leadership and work engagement: A moderated mediation model. Ethics \& Behavior, 30(1), 63-82. https://doi.org/10.1080/10508422.2019.1604232

25. Neubert, M. J., Carlson, D. S., Kacmar, K. M., Roberts, J. A., \& Chonko, L. B. (2009). The virtuous influence of ethical leadership behavior: Evidence from the field. Journal of Business Ethics, 90(2), 157-170. https://doi.org/10.1007/s10551-009-0037-9

26. Piccolo, R. F., Greenbaum, R., Hartog, D. N. D., \& Folger, R. (2010). The relationship between ethical leadership and core job characteristics. Journal of Organizational Behavior, 31(2-3), 259-278. https://doi.org/10.1002/job.627

27. Pillai, R., Schriesheim, C. A., \& Williams, E. S. (1999). Fairness perceptions and trust as mediators for transformational and transactional leadership: A two-sample study. Journal of Management, 25(6), 897-933. https://doi.org/10.1177/014920639902500606

28. Quinn, R. E., \& Spreitzer, G. M. (1997). The road to empowerment: Seven questions every leader should consider. Organizational Dynamics, 26(2), 37-49. https://doi.org/10.1016/S0090-2616(97)90004-8

29. Schaubroeck, J., Lam, S. S., \& Cha, S. E. (2007). Embracing transformational leadership: team values and the impact of leader behavior on team performance. Journal of Applied Psychology, 92(4), 1020. https://doi.org/10.1037/0021-9010.92.4.1020

30. Seibert, S. E., Wang, G., \& Courtright, S. H. (2011). Antecedents and consequences of psychological and team empowerment in organizations: a meta-analytic review. Journal of Applied Psychology, 96(5), 981. https://doi.org/10.1037/a0022676

31. Shamir, B., House, R. J., \& Arthur, M. B. (1993). The motivational effects of charismatic leadership: A selfconcept based theory. Organization Science, 4(4), 577-594. https://doi.org/10.1287/orsc.4.4.577

32. Spector, R., Sivesind, C., \& Kinzenbaw, D. (1986). Pantothenic acid transport through the blood-brain barrier. Journal of Neurochemistry, 47(3), 966-971. https://doi.org/10.1111/j.1471-4159.1986.tb00705.x

33. Spreitzer, G. M. (1995). Psychological empowerment in the workplace: Dimensions, measurement, and validation. Academy of Management Journal, 38(5), 1442-1465. https://doi.org/10.5465/256865

34. Thomas, C. D., Cameron, A., Green, R. E., Bakkenes, M., Beaumont, L. J., Collingham, Y. C., ... \& Hughes, L. (2004). Extinction risk from climate change. Nature, 427(6970), 145. https://doi.org/10.1038/nature02121

35. Thomas, G. F., Tymon Jr, W. G., \& Thomas, K. W. (1994). Communication apprehension, interpretive styles, preparation, and performance in oral briefing. The Journal of Business Communication (1973), 31(4), 311-326. https://doi.org/10.1177/002194369403100405

36. Thomas, K. W., \& Velthouse, B. A. (1990). Cognitive elements of empowerment: An "interpretive" model of intrinsic task motivation. Academy of Management Review, 15(4), 666-681. https://doi.org/10.5465 lamr.1990.4310926

37. Thomas, K. W., \& Velthouse, B. A. (1990). Cognitive elements of empowerment: An "interpretive" model of intrinsic task motivation. Academy of Management Review, 15(4), 666-681. https://doi.org/10.54 65/amr.1990.4310926

38. Treviño, L. K., Weaver, G. R., \& Reynolds, S. J. (2006). Behavioral ethics in organizations: A review. Journal of Management, 32(6), 951-990. https://doi.org/10.1177/0149206306294258 
39. Vigoda-Gadot, E., \& Talmud, I. (2010). Organizational politics and job outcomes: The moderating effect of trust and social support. Journal of Applied Social Psychology, 40(11), 2829-2861. https://doi.org/10.1111/j. 1559-1816.2010.00683.x

40. Williams, L. J., \& Anderson, S. E. (1991). Job satisfaction and organizational commitment as predictors of organizational citizenship and in-role behaviors. Journal of Management, 17(3), 601-617. https://doi.org/10.11 77/014920639101700305

41. Walumbwa, F. O., \& Schaubroeck, J. (2009). Leader personality traits and employee voice behavior: mediating roles of ethical leadership and work group psychological safety. Journal of Applied psychology, 94(5), 1275. https://doi.org/10.1037/a0015848

42. Walumbwa, F. O., Mayer, D. M., Wang, P., Wang, H., Workman, K., \& Christensen, A. L. (2011). Linking ethical leadership to employee performance: The roles of leader-member exchange, self-efficacy, and organizational identification. Organizational Behavior and Human Decision Processes, 115(2), 204-213. https://doi.org/10.1016/j.obhdp.2010.11.002

43. Yamane, T. (1967). Elementary sampling theory. Englewood Cliffs. 